\title{
Agronomic trait selection and pre-germinative treatments in passion fruit hybrid
}

\author{
Cíntia Patrícia Martins Oliveira ${ }^{1 * \mathbb{D}}$, Glaucia Amorim Faria ${ }^{1}$, Antonio Flavio Arruda Ferreira ${ }^{2}$
}

10.1590/0034-737X202269010010

\begin{abstract}
Seed biometry and dormancy overcoming methods should be considered in the passion fruit production chain, in the seedling production stage, because of the different characteristics that condition the seedlings. The objective of this work was to identify and correlate the main biometric characteristics between seeds and seedlings and to select the best pre-germinative treatments in passion fruit hybrids. Seed length, width, thickness and weight were measured, and subsequently subjected to pre-germinative treatments, in a completely randomized design, in a $5 \times 2 \times 3\left(\mathrm{GA}_{3}\right.$ concentrations $\mathrm{x}$ scarification $\mathrm{x}$ hybrids) factorial scheme. In the initial development of the seedlings, the length of the aerial part, the diameter of the stem and the number of leaves were evaluated. Pearson's correlation matrix was estimated between seed and seedling characters and, subsequently, path analysis. The Classification Sum Index was used for the means of the characters under pre-germinative treatment. The best pre-germinative treatment for BRS GA is scarification and soaking in $50 \mathrm{mg}$ of $\mathrm{GA}_{3}$, for BRS SC, soaking in $100 \mathrm{mg}$ of $\mathrm{GA}_{3}$, and for BRS RC, immersion in $50 \mathrm{mg}$ of $\mathrm{GA}_{3}$. Seed morphometric selection is a technique that should be recommended to obtain quality seedlings.
\end{abstract}

Key words: Mulamba \& Mock index; Pearson's correlation; seeds; seedlings.

\section{INTRODUCTION}

Also knownas sour passion fruit, the commercial passion fruit has an expressive participation in the Brazilian market, allowing Brazil to stand out as the largest world's producer (Faleiro \& Junqueira, 2016). In 2019, the cultivation of commercial species of passion fruit occupied a harvested area of 41,584 ha and produced 593,429 tons across the country (IBGE, 2020). However, the productivity achieved in the Brazilian orchards is very low $\left(14.3 \mathrm{t} \mathrm{ha}^{-1}\right)$ (IBGE, 2020) on average, considering that the species has a productive potential to reach more than $40 \mathrm{tha}^{-1}$ (Freitas et al., 2011).

Low productivity occurs mainly due to the lack of adequate technologies in the production system, such as manual pollination, correction of soil acidity and fertility, formation pruning, fertilization, fertigation and phytosanitary control, as well as, through non-adoption of genetically improved cultivars (Faleiro \& Junqueira 2016).
Regarding breeding programs, passion fruit hybrids were developed, with the aim of increasing the productive potential through desirable agronomic characteristics such as high productivity, uniformity in production, high quality fruits and tolerance to the main diseases (Neves et al., 2013). Nevertheless, the number of available commercial passion fruit hybrids is reduced, therefore hampering the access of the farmer to propagating material of high agronomic quality (Krause et al., 2012). In addition, much remains to be reported on the productive behavior of this type of genetic material (Freitas et al., 2011).

According to José et al. (2019), one of the problems faced by passion fruit producers is related to its seminiferous propagation, which presents low and uneven germination, due to dormancy, thus hindering the production of quality seedlings. In order to promote the overcoming of dormancy, the seeds can be mechanically, chemically or physically scarified, to weaken their integument and thus allow the absorption of water (Silva etal., 2019).

\footnotetext{
Submitted on November $26^{\text {th }}, 2020$ and accepted on March $14^{\text {th }}, 2021$.

'Universidade Estadual Paulista, Departamento de Matemática, Ilha Solteira, São Paulo, Brazil. cintia.patricia@unesp.br; glaucia.a.faria@unesp.br

${ }^{2}$ Universidade do Estado do Mato Grosso, Departamento de Agronomia, Alta Floresta, Mato Grosso, Brazil. arrudaferreira.af@gmail.com

*Corresponding author: cintia.patricia@unesp.br
} 
However, Pagliarini et al. (2014) reported that seed biometry is a good strategy both to standardize seedling emergence and to obtain seedlings of similar size or more vigorous. According to Santos et al. (2017), the use of larger seedlings in the cultivation of passion fruit can provide gains in the productive yield in the adult plant, with the improvement in the quality of the fruits, the anticipation of the harvest and the reduction of the cost with inputs.

Hence, the morphological descriptors generate subsidies for the production system, both through the characterization of species and varieties, as well as through information that helps genetic improvement programs (Costa et al., 2009). In this sense, it is feasible and necessary to carry out works involving studies of morphological characterization and correlations between characters of agronomic importance.

Among these studies, the coefficients of correlation allow the comparison between different pairs of characteristics, enabling the identification of easily measurable variables related to these characters, which can facilitate the selection process of agronomic materials with characteristics of interest (Gonçalves et al., 2008). Despite its importance, the simple correlation coefficient does not enable to explain the causes and effects of these relationships, making it impossible to know which type of association exists between the characteristics analyzed (Gonçalves et al., 2003).

Thus, in order to better understand the causes involved in associations among the characters, the path analysis methodology proposed by Wright (1921) has been used. This technique allows the disintegration of the correlation coefficient between the direct and indirect effects of a group of characters in relation to a given character considered of greater importance (basic variable) (Cruz et al., 2014). According to Nogueira et al. (2013), the path analysis allows, in a more practical way, the selection of plants through the indirect effect of other characters that positively interfere on the basic variable.

In order to allow the simultaneous selection of characters, the selection indexes were developed, which are an additional character, established through the optimal combination of several characteristics, which allows the efficient selection of simultaneous characters (Vilarinho et al., 2003; Cruz et al., 2014).

The non-parametric index, the Sum of Rankings, proranking by Mulamba \& Mock (1978), which is easily applicable, consists of the classification of genotypes based on the average of each character. Then, the values attributed to each character are added to obtain the ranking sum in which the final classification of the genotypes is defined (Cruz et al., 2014).
Considering the few studies related to passion fruit hybrids, knowledge about the morphometric aspects of seeds and methods of overcoming dormancy, through the identification of relationships between their characteristics and using selection criteria, which can be evaluated directly in the field, are important for obtaining quality seedlings and consequently for the formation of successful orchards.

Thus, the objective of this work was to select the best pre-germinative treatments in hybrids of passion fruit, as well as to identify and correlate the main biometric characteristics between seed and seedlings, aiming to obtain seedlings with agronomic qualities.

\section{MATERIAL AND METHODS}

The experiment with passion fruit hybrids was conducted from August to September 2018, in a screened agricultural nursery with monofilament mesh, with $50 \%$ shading at the State University of Mato Grosso (UNEMAT), Alta Floresta Campus, located between the geographical coordinates $56^{\circ} 05^{\prime} 10^{\prime \prime} \mathrm{W}, 09^{\circ} 52^{\prime} 32^{\prime \prime} \mathrm{S}$ and altitude of $283 \mathrm{~m}$. The region's climate according to the classification of Köppen-Geiger is Awi (rainy tropical) with rainy summer, dry winter and temperatures ranging from 20 to $38^{\circ} \mathrm{C}$ and average rainfall of $2,750 \mathrm{~mm}$ per year.

Samples of sour passion fruit seeds (BRS Gigante Amarelo, BRS Sol do Cerrado and BRS Rubi do Cerrado) were donated by Embrapa Cerrados / Planaltina-DF. Before treatment application, the seed morphometry was performed, where the following variables were evaluated: seed length $(\mathrm{SL})(\mathrm{mm})$, seed width $(\mathrm{SW})(\mathrm{mm})$, seed thickness (ST) (mm) and seed weight (SW) (mg).

The pre-germinative treatments were distributed in a completely randomized design, in a $5 \times 2 \times 3$ factorial scheme, corresponding to the soaking of the seeds for two hours in a gibberellic acid $\left(\mathrm{GA}_{3}\right)$ solution in the concentrations of $\left(0 ; 25 ; 50 ; 100\right.$ and $\left.250 \mathrm{mg} \mathrm{L}^{-1}\right)$, mechanical scarification of the seeds, on the opposite side of the hilum, with sandpaper no. 100 (with and without scarification), and seeds of three hybrids of passion fruit (BRS Gigante Amarelo-BRS GA, BRS Sol do Cerrado-BRS SC and BRS Rubi do Cerrado-BRS RC), with five replicates per treatment.

The seminiferous material was sown in $300 \mathrm{~mL}$ glasses filled with commercial substrate (TecnoMax $®)$ with five seeds per plot. The irrigation was by micro-sprinkling, three times a day for 30 minutes, with a flow of $7,600 \mathrm{~mm} \mathrm{~s}^{-1}$.

At 30 days after sowing, the following plant characters were measured: stem diameter (SD) $(\mathrm{mm})$, determined at 1 $\mathrm{cm}$ from the substrate level; stem length (SLE) (cm); and number of fully expanded leaves (NL).

The data were analyzed using the analysis of variance method and the null hypothesis, verified by the F test at $5 \%$ significance. The estimates of the correlation 
coefficients between the characters of the seeds and seedlings without the addition of treatments, were calculated using the Pearson's method. Then, the path analysis was performed, considering the seedling variables (SD, SLE and NL) as the dependent variable and the seed variables (SL, SW, ST and SW) as explanatory variables.

For the selection of the best pre-germinative treatment in passion fruit hybrids, the non-parametric index of Mulamba \& Mock (1978) was used, in which the "desired genetic gains" of individual characteristics were used to replace the relative economic weights in the calculation of the selection indexes. To use the proposed modification, it was necessary to use the average the genotypes and the matrices of variance and phenotypic covariance. Thus, it was possible to calculate the coefficients of the indices without designating economic weights. As a result, the obtained index resulted in a maximum gain for each characteristic, according to the relative importance assumed in the specification of the desired gain, subject to the restrictions imposed by the phenotypic and genotypic constitution of the population. All statistical analyses were performed using the computational resources of the Genes Program (Cruz et al., 2014).

\section{RESULTS AND DISCUSSION}

The analysis of variance did not show a triple interaction between the factors evaluated, but there was a significant difference by the F test, demonstrating the existence of genetic variability. Significant interaction was observed between hybrid factors and scarification at $1 \%$ significance for all variables under study, as well as significant interaction between hybrids and $\mathrm{GA}_{3}$ concentration at $1 \%$ significance only for $\mathrm{SD}$ variable and significant interaction between $\mathrm{GA}_{3}$ concentration and scarification at 5\% significance only for SLE variable (Table 1).

The coefficient of variation ranged between 10.46 and $15.31 \%$ (Table 1 ). Such values are considered low according to Gomes (2009), indicating good experimental precision, despite the polygenic nature of the evaluated characters, strongly influenced by the environment and controlled by many genes (Neves et al., 2013).

The lack of significance of the interactions hybrid $\mathrm{x}$ $\mathrm{GA}_{3}$ concentration, for the characteristics stem length and number of leaves per plant and the $\mathrm{GA}_{3}$ concentration $\mathrm{x}$ scarification interaction, for the characteristics of the seedling stem diameter and number of leaves per seedling, indicates similar behavior of these characteristics in the studied treatments.

The Mulamba \& Mock index (1978) was obtained by means of the sum of the number relative to the classification of a particular hybrid in each characteristic, and the corresponding classification ranking is inserted next to each mean to facilitate the interpretation of the results (Table 2).

According to Lessa et al. (2010), the use of the classification sum index is very simple, as it does not need to adjust the units of the characters as well as it does not allow the attribution of weights, to differentiate the characters according to their importance.

The hybrid BRS GA, first classified by the index in question, had the highest score regarding the diameter of the seedling stem (SD), length of the aerial part (SLE) and number of leaves per plant (NL), therefore, it was assigned with the number of classification (or ranking) 1, for all these variables. While the BRS RC hybrid was the last classified by the index, obtaining the lowest score regarding the length of the aerial part (SLE) and the number of leaves per seedling (NL), thus, it was assigned the number of classification (or ranking) 30 for both characters.

The value of the hybrid index is obtained through the sum of the rankings. In this respect, for the hybrid BRS GA, the seeds that received scarification and were immersed in $50 \mathrm{mg} \mathrm{L}^{-1} \mathrm{GA}_{3}$, were those that presented the best combined result for their initial growth (SD, SLE and NL),

Table 1: Analyses of variance of stem diameter (SD), length of the aerial part (SLE), number of leaves (NL) of passion fruit hybrids

\begin{tabular}{|c|c|c|c|c|}
\hline \multirow{2}{*}{$\begin{array}{l}\text { Component } \\
\text { of variation }\end{array}$} & \multirow{2}{*}{ Degrees of freedom } & \multicolumn{3}{|c|}{ Mean squares } \\
\hline & & SD (mm) & SLE (cm) & $\mathbf{N L}$ \\
\hline Hybrids $(\mathrm{H})$ & 2 & $0.08^{\mathrm{ns}}$ & $38.00^{* *}$ & $23.47^{\text {** }}$ \\
\hline Scarification $(\mathrm{S})$ & 1 & $0.05^{\mathrm{ns}}$ & $1.58^{\mathrm{ns}}$ & $4.08^{\mathrm{ns}}$ \\
\hline $\mathrm{GA}_{3}$ concentration $(\mathrm{C})$ & 4 & $0.29^{\mathrm{ns}}$ & $21.80^{* *}$ & $3.89^{*}$ \\
\hline $\mathrm{HxS}$ & 2 & $0.94^{* *}$ & $83.65^{* *}$ & $8.85^{* *}$ \\
\hline $\mathrm{H} \times \mathrm{C}$ & 8 & $0.94^{* *}$ & $5.47^{\mathrm{ns}}$ & $1.22^{\mathrm{ns}}$ \\
\hline $\mathrm{C} \times \mathrm{S}$ & 4 & $0.18^{\mathrm{ns}}$ & $7.25^{*}$ & $0.45^{\mathrm{ns}}$ \\
\hline $\mathrm{H} \times \mathrm{C} \times \mathrm{S}$ & 8 & $0.11^{\mathrm{ns}}$ & $7.55^{\mathrm{ns}}$ & $1.43^{\mathrm{ns}}$ \\
\hline Error & 80 & 0.17 & 4.84 & 0.85 \\
\hline Overall Mean & & 2.78 & 14.36 & 8.83 \\
\hline $\mathrm{CV}(\%)$ & & 14.75 & 15.31 & 10.46 \\
\hline
\end{tabular}

${ }^{\mathrm{n}}$ not-significant, ${ }^{*}$ and ${ }^{* *}$ significant at 5 and $1 \%$ probability by the $\mathrm{F}$ test, respectively.

Rev. Ceres, Viçosa, v. 69, n.1, p. 070-077, jan/feb, 2022 
therefore, this interaction was the best (first selected) based on the Mulamba \& Mock index (Table 2). The need for scarification in this hybrid shows that the tegument is a factor that interferes in the formation of the seedling. According to Zaidan \& Barbedo (2004) when the balance between promoters and germination inhibitors are the cause of dormancy, methods that raise the concentration of germination stimulators or prevent the action of inhibitors such as the direct application of gibberellins can be used.

For the hybrid BRS SC, the best joint-result was observed when the seeds were not subjected to scarification, but only treated with $100 \mathrm{mg} \mathrm{L}^{-1} \mathrm{GA}_{3}$, so, this was the best interaction (first selected) in this hybrid based on the index of Mulamba \& Mock (Table 2). This result corroborates with that observed by Santos et al. (2013), who found that the pre-soaking of yellow passion fruit seeds in $\mathrm{GA}_{3}$ at a concentration of $100 \mathrm{mg} \mathrm{L}^{-1}$ stimulated the formation of seedlings. According to Carvalho et al. (2012), the exogenous application of gibberellins promotes the expression of genes that control the synthesis of enzymes involved in the degradation of cell walls of the endosperm, inducing the growth of the embryo and stimulating the germination process.

On the other hand, for the hybrid BRS RC, the best interaction by this index for the characteristics evaluated simultaneously was found when the seeds were not scarified, but only treated with $25 \mathrm{mg} \mathrm{L}^{-1}$ of $\mathrm{GA}_{3}$ (Table 2). Low concentrations of $\mathrm{GA}_{3}$ can activate the production of the enzymes xyloglucan endotransglycosylase, promoting loosening of the cell wall, and consequently the growth of tissue; however, this growth may be inhibited when $\mathrm{GA}_{3}$ is in higher concentrations (Taiz et al., 2017).

Table 2: Means of the original data $(\underline{x})$ and ranking of the characters stem diameter (SD), arial part length (SLE) and number of leaves $(\mathrm{NL})$ for the calculation on the sum index of the classification in passion flower hybrids

\begin{tabular}{|c|c|c|c|c|c|c|c|c|}
\hline \multicolumn{3}{|c|}{ Factor } & \multicolumn{6}{|c|}{ Phenotypic Values (Classification) } \\
\hline \multirow{2}{*}{ HYB } & \multirow{2}{*}{ SCF } & \multirow{2}{*}{$\mathbf{G A}_{3}$} & \multicolumn{2}{|c|}{ SD } & \multicolumn{2}{|c|}{ SLE } & \multicolumn{2}{|c|}{ NL } \\
\hline & & & $\underline{x}$ & Ranking & $\underline{x}$ & Ranking & $\underline{x}$ & Ranking \\
\hline \multirow{10}{*}{ BRS GA } & \multirow{5}{*}{ Without } & 0 & 2.69 & 22 & 13.30 & 21 & 9.40 & 8 \\
\hline & & 25 & 2.82 & 14 & 13.80 & 19 & 9.60 & 3 \\
\hline & & 50 & 2.85 & 13 & 13.20 & 23 & 9.40 & 9 \\
\hline & & 100 & 2.82 & 15 & 14.30 & 13 & 9.20 & 12 \\
\hline & & 250 & 2.26 & 30 & 13.25 & 22 & 8.50 & 20 \\
\hline & \multirow{5}{*}{ With } & 0 & 2.79 & 17 & 14.50 & 12 & 9.00 & 14 \\
\hline & & 25 & 2.93 & 7 & 16.10 & 4 & 9.60 & 4 \\
\hline & & $50^{1}$ & 3.10 & 1 & 17.10 & 2 & 10.40 & 1 \\
\hline & & $100^{2}$ & 3.05 & 3 & 19.20 & 1 & 9.60 & 5 \\
\hline & & $250^{3}$ & 2.95 & 5 & 16.90 & 3 & 10.40 & 2 \\
\hline \multirow{10}{*}{ BRS SC } & \multirow{5}{*}{ Without } & 0 & 2.56 & 27 & 12.75 & 26 & 8.25 & 22 \\
\hline & & 25 & 2.81 & 16 & 14.00 & 16 & 9.20 & 13 \\
\hline & & $50^{2}$ & 2.95 & 6 & 14.10 & 14 & 9.60 & 6 \\
\hline & & $100^{1}$ & 2.97 & 4 & 15.70 & 8 & 9.60 & 7 \\
\hline & & 250 & 2.84 & 12 & 14.10 & 15 & 8.80 & 16 \\
\hline & \multirow{5}{*}{ With } & 0 & 2.43 & 29 & 12.70 & 27 & 7.60 & 28 \\
\hline & & 25 & 2.46 & 28 & 11.70 & 28 & 8.40 & 21 \\
\hline & & 50 & 2.69 & 23 & 14.00 & 17 & 9.40 & 10 \\
\hline & & $100^{3}$ & 3.09 & 2 & 14.00 & 18 & 9.40 & 11 \\
\hline & & 250 & 2.71 & 20 & 11.30 & 29 & 8.20 & 23 \\
\hline \multirow{10}{*}{ BRS RC } & \multirow{5}{*}{ Without } & 0 & 2.76 & 18 & 13.10 & 25 & 8.20 & 24 \\
\hline & & $25^{1}$ & 2.92 & 8 & 15.50 & 10 & 9.00 & 15 \\
\hline & & 50 & 2.91 & 9 & 15.20 & 11 & 8.80 & 17 \\
\hline & & $100^{3}$ & 2.89 & 11 & 15.70 & 9 & 8.80 & 18 \\
\hline & & $250^{2}$ & 2.90 & 10 & 15.90 & 5 & 8.60 & 19 \\
\hline & \multirow{5}{*}{ With } & 0 & 2.71 & 21 & 13.20 & 24 & 8.00 & 25 \\
\hline & & 25 & 2.59 & 25 & 15.90 & 6 & 7.80 & 27 \\
\hline & & 50 & 2.59 & 26 & 15.80 & 7 & 8.00 & 26 \\
\hline & & 100 & 2.60 & 24 & 13.38 & 20 & 7.60 & 29 \\
\hline & & 250 & 2.72 & 19 & 11.20 & 30 & 6.60 & 30 \\
\hline
\end{tabular}

$1,{ }^{2},{ }^{3}$ first, second and third interaction, respectively select by the index of Mulamba \& Mock for each hybrid. 
In general, it is stated that the Mulamba \& Mock index provided an adequate classification of these hybrids, being efficient to simultaneously classify the main characteristics in the initial development of seedlings (SLE, SD, NL), considering that the index allows a selective explanation of the best pre-germinative strategies, which varied in the three evaluated hybrids. According to Araujo et al. (2008), within a single species of passion fruit, there is significant variability for several characters of agronomic interest.

According to Pearson's correlation analysis (Table 3), it can be seen that the variables analyzed showed significant degrees of associations, with estimated values greater than 0.90; therefore, indicating a strong correlation (Neves et al., 2013), with high, positive and significant phenotypic correlations ( $\mathrm{P}<0.05$ ) between SL with SD (0.959), ST with SW (0.955), SLE with NL (0.949) and significant $(\mathrm{P}<0.01)$ between SW with SLE $(0.989)$. And negative and significant phenotypic correlations $(\mathrm{P}<0.05)$, of magnitudes greater than 0.90 between the NL with SL (0.966) and with SD (-0.984), however (Table 3).

It is possible that the high positive genetic correlations occurred due to the pleiotropism or gene connection that causes a transient correlation, mainly in populations originated from the crossing between divergent strains (Falconer \& Mackay, 1996).

The results demonstrate the existence of significant correlations between many of the characteristics in the analyzed seeds and seedlings. This allows the use of simple assessments, such as seed biometry or plant biometry to estimate quality parameters during the selection processes of passion fruit seedlings.

In this regard, the variables involving the seed biometry showed significant correlation only between seed weight and seed thickness and a positive one between these characteristics, in which the $\mathrm{x}$ and y pairs proportionally increase or decrease, presenting a bivariate normality (Assis et al., 2020).

A divergent result was observed in passion fruit seeds of the Caatinga biome by Assis et al. (2020), who found that the correlations between thickness and length and thickness and width showed simple direct or positive linear correlation, while the correlation between weight and thickness and weight and width obtained insignificant correlation values. When evaluating passion fruit seeds submitted to different levels of fertilization, Rodrigues (2015) observed that the heavier seeds are also wider, just as the lighter ones are also the narrower.

Thus, the correlation between biometric characters may be an important tool to identify genetic variability within populations of the same species, the relationships between this variability and the environmental factors (Araujo et al., 2008). In addition, the distinction and characterization of seeds through linear dimensions is a promising tool for the production of quality seedlings of fruit cultivars (Ruprecht et al., 2015).

In this context, the length of the seed obtained a strong positive correlation with the diameter of the stem and the width of the seeds obtained a strong positive correlation with the length of the aerial part (Table 3), which indicates that the expression of characters that are part of the morphometric components of the seed (length and width) is increased due to the influence of the characters stem diameter and length of the aerial part of hybrid of passion fruit plants. Larger seeds generally have well-formed embryos with greater reserves, and consequently, more vigorous plants (Carvalho \& Nakagawa, 2012).

Besides being used in an attempt to explain differences in growth, of a genetic order or resulting from interactions of the environment, the analysis of characteristics in the initial growth also allows the identification of promising seedlings with high productive potential (Lima et al., 2007). As seen in Table 3, the variables that involve initial seedling growth have a high correlation with each other, possibly due to the dependence between them and because some of these variables come from others.

According to Nogueira et al. (2012), estimates of positive coefficient of correlation indicate that as one variable increases, the other tends to increase, while estimates of negative correlation coefficients indicate that as one variable increases, the other tends to decrease.

Table 3: Estimates of phenotypic correlations between the characters length (SL), width (SWI), thickness (ST) and weight of the seeds (SWE); and stem diameter (SD), stem length (SLE) and number of leaves (NC) in passion fruit hybrids

\begin{tabular}{llllllcc}
\hline & SL & SWI & S T & SWE & SD & SLE & NL \\
\hline SL & 1 & $-0.744^{\text {ns }}$ & $0.824^{\text {ns }}$ & $0.820^{\text {ns }}$ & $0.959^{*}$ & $-0.837^{\text {ns }}$ & $-0.966^{*}$ \\
SWI & $-0.742^{\text {ns }}$ & 1 & $-0.538^{\text {ns }}$ & $-0.354^{\text {ns }}$ & $-0.874^{\text {ns }}$ & $0.989^{* *}$ & $0.890^{\text {ns }}$ \\
ST & $0.824^{\text {ns }}$ & $-0.538^{\text {ns }}$ & 1 & $0.955^{*}$ & $0.678^{\text {ns }}$ & $-0.626^{\text {ns }}$ & $-0.782^{\text {ns }}$ \\
SWE & $0.820^{\text {ns }}$ & $-0.354^{\text {ns }}$ & $0.955^{*}$ & 1 & $0.629^{\text {ns }}$ & $-0.475^{\text {ns }}$ & $-0.706^{\text {ns }}$ \\
SD & $0.959^{*}$ & $-0.874^{\text {ns }}$ & $0.678^{\text {ns }}$ & $0.629^{\text {ns }}$ & 1 & $-0.934^{\text {ns }}$ & $-0.984^{*}$ \\
SLE & $-0.837^{\text {ns }}$ & $0.989^{* *}$ & $-0.626^{\text {ns }}$ & $-0.475^{\text {ns }}$ & $-0.934^{\text {ns }}$ & 1 & $0.949^{*}$ \\
NL & $-0.966^{*}$ & $0.890^{\text {ns }}$ & $-0.782^{\text {ns }}$ & $-0.706^{\text {ns }}$ & $-0.984^{*}$ & $0.949^{*}$ & 1
\end{tabular}

${ }^{*}$ and ${ }^{* *}$ significant at $5 \%$ and $1 \%$ respectively; ${ }^{\text {ns }}$ - not significant by the Pearson's method. 
Table 3 shows that the number of leaves per seedling had a strong negative correlation with the diameter of the seedling stem, and a strong positive correlation with the length of the aerial part, indicating that the selection of seedlings with a greater number of leaves would result in the selection of seedlings with smaller diameter and greater length of the aerial part.

However, Junior et al. (2015) when evaluating morphological variables in eucalyptus seedlings, indicated the stem diameter as a reliable variable, considering that the height of the seedling can be greatly influenced by environmental variations, population density and nutritional levels. Hence, although the correlation analysis indicates a high degree of dependency between variables, it can generate misunderstandings regarding the relationship between two variables, not being a real measure of cause and effect (Negreiros et al., 2008).

As a result, the path analysis must be performed to unfold the correlation coefficient, investigating the cause and effect relationships, providing the phenotypic coefficients (Zuffo et al., 2018).

The direct and indirect effects of the explanatory variables on the basic variables are shown in Table 4, where the coefficient of determination $\left(\mathrm{R}^{2}\right)$ was equal to the unit, which shows that the adopted explanatory model expressed the cause-effect relationship of the primary variables in sour passion fruit.

Thus, with the eigen-value of the coefficient of determination and the low effect of the residual variable, it can be inferred that the analysis with four characters proved to be reliable to explain the effects of the characters on the basic variables (Cruz et al., 2014).

The primary characteristic SL had a direct effect of high magnitude and the same direction only on the basic variable SD. The other primary characteristics showed direct effects of low magnitude or of a sign contrary to the correlation and, therefore, do not have a cause and effect relationship on the basic variables stem diameter (SD), stem length (SLE) and number of leaves (NL) (Table 4).

On the other hand, the primary characteristics ST and SWE act indirectly on the basic variable SD, especially via SL. Thus, it appears that the seed length is directly involved in obtaining seedlings with larger stem diameters.

Silva et al. (2010) in a study on the influence of seed size on jackfruit seedlings, found that extra-large seeds provided the largest stem diameter, while small seeds resulted in the smallest diameter. Nevertheless, Souza et $a l$. (2017b), studying the influence of seed size on CamuCamu seedlings, found that small seeds had higher height, diameter and average number of leaves, while large seeds

Table 4: Estimates of the direct and indirect effects of the characters length (SL), width (SWI), thickness (ST) and seed weight (SWE) on the basic variables stem diameter (SD), stem length (SLE) and number of leaves (NL)

\begin{tabular}{|c|c|c|c|c|}
\hline \multirow{2}{*}{$\begin{array}{l}\text { Primary } \\
\text { characteristics }\end{array}$} & \multirow[t]{2}{*}{ Mode of Association } & \multicolumn{3}{|c|}{ Basic variable estimate } \\
\hline & & SD & SLE & NL \\
\hline \multirow{5}{*}{ SL } & Direct effect on the basic variable & 0.85 & -1.10 & -2.55 \\
\hline & Indirect effect via SWI & 0.30 & -0.06 & 0.93 \\
\hline & Indirect effect via ST & -0.36 & -1.04 & -2.37 \\
\hline & Indirect effect via SWE & 0.17 & 1.36 & 3.02 \\
\hline & Total & 0.96 & -0.84 & -0.97 \\
\hline \multirow{5}{*}{ SWI } & Direct effect on the basic variable & -0.40 & 0.08 & -1.25 \\
\hline & Indirect effect via SL & -0.63 & 0.82 & 1.90 \\
\hline & Indirect effect via ST & 0.23 & 0.68 & 1.55 \\
\hline & Indirect effect via SWE & -0.07 & -0.59 & -1.31 \\
\hline & Total & -0.87 & 0.99 & 0.89 \\
\hline \multirow{5}{*}{ ST } & Direct effect on the basic variable & -0.43 & -1.26 & -2.87 \\
\hline & Indirect effect via SL & 0.70 & -0.90 & -2.10 \\
\hline & Indirect effect via SWI & 0.22 & -0.04 & 0.67 \\
\hline & Indirect effect via SWE & 0.19 & 1.59 & 3.52 \\
\hline & Total & 0.68 & -0.63 & -0.78 \\
\hline \multirow{5}{*}{ SWE } & Direct effect on the basic variable & 0.20 & 1.66 & 3.69 \\
\hline & Indirect effect via SL & 0.70 & -0.90 & -2.09 \\
\hline & Indirect effect via SWI & 0.14 & -0.03 & 0.44 \\
\hline & Indirect effect via ST & -0.41 & -1.21 & -2.74 \\
\hline & Total & 0.63 & -0.48 & -0.71 \\
\hline \multicolumn{2}{|c|}{ Coefficient of determination $\left(\mathrm{R}^{2}\right)$} & 1 & 1 & 1 \\
\hline \multicolumn{2}{|c|}{ Residue variable effect } & 0 & 0 & 0 \\
\hline
\end{tabular}


showed lower values for these variables. Carneiro (1995) considered the stem diameter as a good isolated variable to be used for a better classification of seedlings in terms of quality influenced by the size and weight of the seeds.

On the hand, the seed weight has a greater direct effect on the basic variable SLE. This high direct effect indicates a cause and effect relationship. A result similar to SLE was also observed in the NL (Table 4), indicating that the seed weight is the major determinant of changes in both SLE and NL.

The weight of the seed has been shown to be an indication of physiological quality, indicating that heavier seeds usually perform better than the light ones (Souza et al., 2017a). According to Carvalho \& Nakagawa (2012), in the same species, the heavier seeds receive a greater amount of nutrients during their development, resulting in embryos with a greater quantity of reserves, and consequently more vigorous seeds, which will originate more developed seedlings.

According to Cruz et al. (2014), if the correlation is high and the direct effect is low, the simultaneous selection of variables with emphasis on those with significant indirect effects is the best way to result in satisfactory gains in the main variable. Thus, for the basic variables SLE and NL, direct effects of low magnitude or sign contrary to the correlation for SL, LS, ST were found, indicating the inexistence of their cause and effect on the basic variables. Thus, most of the correlation obtained in SL and ST over SLE and NLP was explained by the indirect effect via SW, while in SW it was explained by the indirect effect via SL and ST (Table 4).

The identification of characters involved in the initial growth of seedlings allows gains in productive yield in the adult plant (Lima et al., 2007). Thus, the information obtained in the characters of the seeds (length, width, thickness and weight) and seedlings (length of the aerial part, stem diameter and number of leaves) through Pearson's correlation, path analysis and Mulamba \& Mock index are important for obtaining quality seedlings and consequently the formation of successful orchards. In addition, this information is relevant to improve the knowledge of the agronomic behavior of yellow passion fruit hybrids.

\section{CONCLUSIONS}

Soaking the seeds for two hours in a gibberellic acid $\left(\mathrm{GA}_{3}\right)$ solution promotes the initial development of passion fruits hybrids. Thus, the best pre-germinative treatment for BRS GA is scarification and immersion in 50mg GA, while for BRS SC, only the immersion in $100 \mathrm{mg} \mathrm{GA}_{3}$ and for BRS RC only the immersion in $25 \mathrm{mg} \mathrm{GA}_{3}$.

Seed morphometric selection is a technique that should be recommended to obtain seedlings with desired agronomic characteristics. The Mulamba \& Mock index is efficient for the simultaneously classification of the main characteristics in the growth of passion fruit hybrids.

The weight of the seeds is the most correlated character and with the greatest direct effect on the length of the aerial part and the number of leaves of passion fruit seedlings. The seed length is the most correlated character and has the greatest direct effect on the stem diameter of passion fruit seedlings.

\section{ACKNOWLEDGEMENTS}

The authors would like to thank to Embrapa Cerrados (Dr. Nilton Tadeu Vilela Junqueira, Dr. Onildo Nunes de Jesus and Dr. Fábio Gelape Faleiro) for the donated seminiferous material. The authors declare that they have no conflict of interest.

\section{REFERENCES}

Araujo FP, Silva N \& Queiroz MA (2008) Divergência genética entre acessos de Passiflora cincinnata Mast com base em descritores morfoagronômicos. Revista Brasileira de Fruticultura, 30:723-730.

Assis JP, Sousa RP, Linhares PCF, Cardoso EA, Rodrigues WM, Pereira JO, Sousa RP, Pereira BBM, Silva NV, Alves LS \& Abrantes EG (2020) Biometric evaluation of Passiflora cincinnata seeds obtained from the herbaceous extract of the caatinga biome. International Journal of Advanced Engineering Research and Science, 7:57-67.

Carneiro JGA (1995) Produção e controle de qualidade de mudas florestais. Curitiba, UFPR/FUPEF. 451 p.

Carvalho MAF, Paiva R, Vargas DP, Porto JMP, Herrera RC \& Stein VC (2012) Germinação in vitro de Passiflora gibertii NE Brown com escarificação mecânica e ácido giberélico. Semina: Ciências Agrárias, 33:1027-1032.

Carvalho NM \& Nakagawa J (2012) Sementes: ciência, tecnologia e produção. $5^{\text {a }}$ ed. Jaboticabal, Funep. 590 p.

Costa AM, Vicentini GC, Brandão LS, Silva KN, Santos ALB, Faleiro FG \& Junqueira NTV (2009) Descritores morfológicos quantitativos da Passiflora setacea variedade 'BRS Pérola do Cerrado'obtidos na safra chuvosa e seca. In $5^{\circ}$ Congresso Brasileiro de Melhoramento de Plantas, Vitória. Anais, Embrapa. p.1-4.

Cruz CD, Carneiro PCS \& Regazzi AJ (2014) Modelos biométricos aplicados ao melhoramento genético. $3^{\mathrm{a}}$ ed. Viçosa, Editora UFV. 668p.

Falconer DS \& Mackay TFC (1996) Introduction to quantitative genetics. $4^{a}$ ed. Longman, Essex UK. 464p.

Faleiro FG \& Junqueira NTV (2016) Maracujá: o produtor pergunta, a Embrapa responde. Brasília, Embrapa. 341 p.

Freitas JPX, Oliveira EJ, Cruz Neto AJ \& Santos LR (2011) Avaliação de recursos genéticos de maracujazeiro-amarelo. Pesquisa Agropecuária Brasileira, 46:1013-1020.

Gonçalves GM, Viana AP, Reis LSD, Bezerra Neto FV, Amaral Júnior ATD \& Reis LSD (2008) Correlações fenotípicas e genético-aditivas em maracujá-amarelo pelo delineamento I. Ciência e Agrotecnologia, 32:1413-1418.

Gonçalves MC, Correa AM \& Destro D (2003) Correlations and path analysis of common bean grain yield and its primary components. Crop Breeding and Applied Biotechnology, 3:217222 . 
IBGE - Instituto Brasileiro de Geografia e Estatística (2020) Produção Agrícola 2019. Available at: <https://sidra.ibge.gov.br/tabela/5457> . Accessed on: July 4th, 2020.

José S, Salomão A, Melo CC, Cordeiro IDM \& Gimenes M (2019) Tratamentos pré-germinativos na germinação de sementes de maracujás silvestres. Brasilia, Embrapa Recursos Genéticos e Biotecnologia. 20p. (Boletim de Pesquisa e Desenvolvimento, 351).

Junior NSN, Nicoletti MF \& Navroski MC (2015) Modelagem de variáveis morfológicas em mudas de Eucalyptus dunnii. Floresta, 45:809-818.

Krause W, Souza RS, Neves LG, Carvalho MLS, Viana AP \& Faleiro FG (2012) Ganho de seleção no melhoramento genético intrapopulacional do maracujazeiro amarelo. Pesquisa Agropecuária Brasileira, 47:51-57.

Lessa LS, Ledo CADS, Santos VDS, Silva SDOE \& Peixoto CP (2010) Seleção de híbridos diplóides (AA) de bananeira com base em três índices não paramétricos. Bragantia, 69:525-534.

Lima JF, Peixoto CP \& Silva CA (2007) Índices fisiológicos e crescimento inicial de mamoeiro (Carica papaya L.) em casa de vegetação. Ciência e agrotecnologia, 31:1358-1363.

Mulamba NN \& Mock JJ (1978) Improvement of yield potential of the ETO blanco maize (Zea mays L.) population by breeding for plant traits [Mexico]. Egyptian Journal of Genetics and Cytology, 7:40-51.

Negreiros JRS, Alexandre RS, Alvares VDS, Bruckner CH \& Cruz CD (2008) Divergência genética entre progênies de maracujazeiro-amarelo com base em características das plântulas. Revista Brasileira de Fruticultura, 30:197-201.

Neves CG, Jesus OND, Ledo CADS \& Oliveira EJD (2013) Avaliação agronômica de parentais e híbridos de maracujazeiro-amarelo. Revista Brasileira de Fruticultura, 35:191-198.

Nogueira APO, Sediyama T, Sousa LB, Hamawaki OT, Cruz CD \& Pereira DG (2012) Análise de trilha e correlações entre caracteres em soja cultivada em duas épocas de semeadura. Bioscience Journal, 28:877-888

Nogueira PAG, Zoz T, Nunes KGS, Filho PRR \& Venturini GC (2013) Correlação e análise de trilha de produtividade de grãos e seus componentes e caracteres de planta em milho. In: Congresso de Iniciação Científica das Faculdades Integradas de Ourinhos, Ourinhos. Anais, FIO/FEMM. p. 01-20.

Pagliarini MK, Nasser MD, Nasser FACM, Cavichioli JC \& Castilho RMM (2014) Influência do tamanho de sementes e substratos na germinação e biometria de plântulas de jatobá. Tecnologia \& Ciência Agropecuária, 8:33-38.

Gomes FP (2009) Curso de estatística experimental. $15^{\mathrm{a}}$ ed. Piracicaba, Fealq. 451p.
Rodrigues DL (2015) Qualidade de sementes e variabilidade genética de progênies $\mathrm{CO}_{3}$ de em função da adubação e do armazenamento. Tese de Doutorado. Universidade Estadual Norte Fluminense, Campo dos Goytacazes. 99p.

Ruprecht E, Fenesi A, Fodor EI, Kuhn T \& Tökölyi J (2015) Shape determines fire tolerance of seeds in temperate grasslands that are not prone to fire. Perspectives in Plant Ecology, Evolution and Systematics, 17:397-404.

Santos CAC, Vieira EL, Peixoto CP \& Ledo CAS (2013) Germinação de sementes e vigor de plântulas de maracujazeiro amarelo submetidos à ação do ácido giberélico. Bioscience Journal, 29:400-407.

Santos VA, Ramos JD, Laredo RR, Silva FOR, Chagas EA \& Pasqual M (2017) Produção e qualidade de frutos de maracujazeiroamarelo provenientes do cultivo com mudas em diferentes idades. Revista de Ciências Agroveterinárias, 16:33-40.

Silva KS, Mendonça V, Medeiros LF, Freitas PSC \& Góis GB (2010) Influência do tamanho da semente na germinação e vigor de mudas de jaqueira (Artocarpus heterophyllus Lam.). Revista Verde de Agroecologia e Desenvolvimento Sustentável, 5:217-221.

Silva AL, Hilst PC, Dias DCFS \& Rogalski M (2019) Superação da dormência de sementes de Passiflora elegans Mast., Passifloraceae. Revista Verde de Agroecologia e Desenvolvimento Sustentável, 14:406-411.

Souza ADG, Spinelli VM, Souza ROD, Smiderle OJ \& Bianchi VJ (2017a) Optimization of germination and initial quality of seedlings of Prunus persica tree rootstocks. Journal of Seed Science, 39:166-173.

Souza OM, Smiderle OJ, Souza AG, Chagas EA, Chagas PC, Bacelar-Lima CG \& Morais BS (2017b) Influência do tamanho da semente na germinação e vigor de plântulas de populações de Camu-Camu. Scientia Agropecuaria, 8:119-125.

Taiz L, Zeiger E, Møller IM \& Murphy A (2017) Fisiologia e desenvolvimento vegetal. $6^{\text {a }}$ ed. Porto Alegre, Artmed Editora. $858 \mathrm{p}$.

Wright S (1921) Correlation and causation. Journal of Agricultural Research, 20:557-585.

Vilarinho AA, Viana JMS, Santos JFD \& Câmara TMM (2003) Eficiência da seleção de progênies S1 e S2 de milho-pipoca, visando à produção de linhagens. Bragantia, 62:09-17.

Zaidan LBP \& Barbedo CJ (2004) Quebra de dormência em sementes. In: Ferreira AG \& Borghetti F (Eds.) Germinação: do básico ao aplicado. Porto Alegre, Artmed. p.135-146.

Zuffo AM, Ribeiro ABM, Bruzi AT, Zambiazzi EV \& Fonseca WL (2018) Correlações e análise de trilha em cultivares de soja cultivadas em diferentes densidades de plantas. Cultura Agronômica: Revista de Ciências Agronômicas, 27:78-90. 